\title{
Temporal and spatial regulation of the symbiotic genes of Rhizobium meliloti in planta revealed by transposon Tn5-gusA
}

\author{
Shashi B. Sharma ${ }^{1}$ and Ethan R. Signer \\ Department of Biology, Massachusetts Institute of Technology, Cambridge, Massachusetts 02139 USA
}

\begin{abstract}
Tn5-gusA promoter/probe transposons have been constructed that fuse the Escherichia coli gusA reporter gene transcriptionally or translationally with a target promoter. These have been used to monitor expression of Rhizobium meliloti symbiotic genes within alfalfa nodules. Fusions in all 11 nod genes studied show the same pattern of expression: first on the root surface, then throughout the developing nodule, then mainly in the nodule meristem, falling off progressively through the central region, and then disappearing. In contrast, fusions in all five nif genes studied, all four fix genes, and syrM show a second, different pattern: expression beginning later, first throughout the nodule except for the meristem, strongest just behind the meristem, and falling off progressively through the central region. Novel features revealed by these studies include nod expression in the meristem, regulated in planta expression of control genes nodD1 and nodD3, disappearance of nod expression late in organogenesis, and properties of $S y r M$.
\end{abstract}

[Key Words: Rhizobium meliloti; Tn5-gusA; nod genes]

Received October 16, 1989; revised version accepted January 8, 1990.

Rhizobia elicit the formation of root nodules on leguminous hosts by means of a complex series of developmental changes (Newcomb 1981). The invading bacteria first induce root hairs to curl into "shepherd's crooks" and stimulate cell divisions in the plant root cortical layer, giving rise to a new meristem (Callaham and Torrey 1981). Then, bacteria penetrate the curled root hair and invade the growing meristem through a tubular polysaccharide structure called the infection thread. Finally, the bacteria surrounded by a plant-derived membrane are released into the interior of plant cells, where they differentiate into morphologically distinct forms called bacteroids that can fix atmospheric nitrogen into ammonia.

Both nodule formation and symbiotic nitrogen fixation require the developmentally regulated expression of bacterial genes. One group, the nod genes (Fig. 1), is involved in nodule formation. The "common" nod genes, $\operatorname{nod} A, \operatorname{nod} B$, and nodC, are functionally and structurally conserved among different rhizobia (Kondorosi et al. 1984; Fisher et al. 1985). In Rhizobium meliloti three regulatory genes, nodD1, nodD2, and nodD3, activate these and other nod genes in the presence of plant root exudates (Mulligan and Long 1985, 1989; Peters et al. 1986; Honma and Ausubel 1987), and help to determine host range by their differential response to various exudate flavonoids (Spaink et al. 1987; Gyorgypal et al.

1Present address: Department of Scientific and Industrial Research, Grasslands Division, Palmerston North Centre, New Zealand.
1988). The host-specific nodulation (hsn) genes, nodH, $\operatorname{nod} F, \operatorname{nod} E, \operatorname{nod} G, \operatorname{nod} P$, and $\operatorname{nod} Q$, in which mutations cannot be complemented by cloned genes from other rhizobia (Kondorosi et al. 1984; Debelle and Sharma 1986; Debelle et al. 1986; Cervantes et al. 1989), also help determine host range, at least in part, by modifying the growth-promoting substance synthesized by nodA and nodB (Schmidt et al. 1988; Faucher et al. 1989). Two additional genes, nodI, and nodI (nod region IIa; Debelle et al. 1986; Evans and Downie 1986), which are probably part of the nodABC operon, affect the kinetics of nodulation.

Another group of genes, pivotal to symbiotic nitrogen fixation, includes those coding for nitrogenase (nif) and others required for fixation whose precise functions are not known $(f i x)$. In $R$. meliloti, nif genes include nifH, nifD, and nifK (Ruvkun et al. 1982), nifN (Aguilar et al. 1987), and nifA and nifB (Buikema et al. 1985, 1987; and the cotranscribed $f d x N$ gene for ferredoxin; Klipp et al. 1989), whereas fix genes include fix $A$, fix $B$, fix $C$, and fixX (Earl et al. 1987), fixL and fixJ (David et al. 1988), fixK and fixN (Batut et al. 1989), and fixG, fixH, and fixI (Kahn et al. 1989). These genes are induced in bacteroids by the FixL and FixJ proteins, which belong to a conserved family of two-component regulators (David et al. 1988). FixL recognizes a signal present in the low oxygen symbiotic environment and modulates the activity of FixJ which, in turn, activates nif $A$ and fix $K$ to produce positive activators of other nif and fix genes. Both nifA and fixK can also be induced by microaerobic culture 


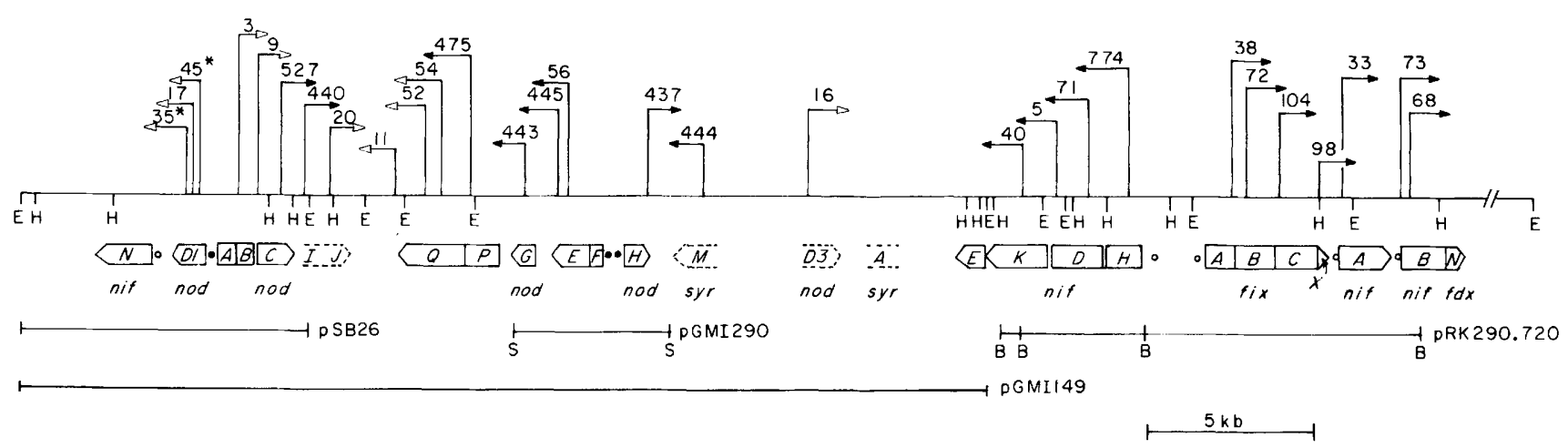

Figure 1. Map of genes and Tn5-gusA insertions. Above the restriction map are the positions of each insertion, shown by a vertical line with the number of the mutation at the top; open and solid arrows represent insertions of Tn5-gusA1 (or Tn5-gusA7, 35 and 45) and $\operatorname{Tn} 5-$ gus $A 2$, respectively; the arrowhead indicates the direction of transcription or translation of gus $A$. The positions of insertions 98 and 437 are based on the sequence of the insertion junction determined with a gus $A$-specific primer (sequence data not shown). Below the map are restriction sites and extent of genes, with the arrow indicating direction of transcription that was determined on the basis of sequence data; dashed lines indicate that sequences of the genes are not available. nodD1 insertions are on pSB26; insertions 437,443, and 445 are on pGMI290; insertions in nif and fix genes are on pRK290.720; all remaining insertions are on pGMI149. (•) Luteolin-inducible promoter with nod box; (ㅇ) microaerobically inducible promoter, (E) EcoRI; (H) HindIII; (S) SmaI; (B) BgIII.

and by constitutive production of FixJ (Ditta et al. 1987; Hertig et al. 1989|. Other NifA-inducible genes are not involved in nitrogen fixation but, rather, in the synthesis of an opine-like compound (Murphy et al. 1988).

Other $R$. meliloti genes involved in symbiosis include the exo and exp genes for exopolysaccharide synthesis (Keller et al. 1988; Long et al. 1988; Glazebrook and Walker 1989); $n d v$ genes for neutral $\beta$-1,2-cyclic glucan production (Dylan et al. 1986; Stanfield et al. 1988); some lps genes for lipopolysaccharide synthesis (Williams et al. 1990); dct genes (Watson et al. 1988) for C4dicarboxylate transport; and $s y r M$, which regulates other symbiotic genes (Mulligan and Long 1989).

Our knowledge of how these symbiotic genes are regulated in planta is fragmentary. In this paper we describe an easy and rapid system for in planta studies based on Tn5-gusA transposons that fuse target operons or genes with the promoterless reporter gusA gene of Escherichia coli. The gusA gene product, $\beta$-glucuronidase, can be easily and accurately assayed by spectrophotometric, fluorometric, and histochemical techniques (Jefferson et al. 1986, 1987). Because neither $R$. meliloti nor alfalfa have detectable $\beta$-glucuronidase activity, gus $A$ fusions can be used to monitor in planta expression of $R$. meliloti genes during nodule development. Using Tn5-gusA fusions, we show that the expression of symbiotic genes is temporally regulated and spatially restricted during nodule development with genes that act early (nod), showing a different pattern from genes that act late (nif, fix, syrM).

\section{Results}

\section{Construction of Tn5-gusA transposons}

Construction of Tn5-gusA1, a transcriptional operon fusion transposon, is shown in Figure 2. Tn5-gusA1 includes the first $25 \mathrm{bp}$ of IS50L, which is sufficient for transposition (Johnson and Reznikoff 1983); translation terminators in all reading frames; and a Shine-Dalgarno sequence placed so as to allow initiation of gusA translation. Tn5-gusA2 (Fig. 2), a translational gene fusion transposon, is similar but does not include the third translation terminator or a Shine-Dalgarno sequence; here, the promoterless gusA is fused to the first $25 \mathrm{bp}$ of IS50L behind translation terminators in the two incorrect reading frames with respect to the gusA gene. Other derivatives of $\operatorname{Tn} 5$-gusA 1 and $\operatorname{Tn} 5$-gus $A 2$ were constructed by deletion or replacement of the genes conferring drug resistance (Fig. 2). Delivery vehicles carrying either Tn5-gusA1 or Tn5-gusA2 in $\lambda b 221$ cI857 Oam29 Pam80 (Table 1) can be used to mutagenize any sup0 E. coli or other bacterial strain carrying a functional $1 a m B$ receptor (Ludwig 1987), and vehicles derived from plasmid pRK600 (Table 1), which is self-transmissable but fails to replicate in many bacterial hosts, can be used for suicide mutagenesis by mating. Both types of delivery vehicles have been used to mutagenize $E$. coli and R. meliloti [pRK600 $\Omega$ :: Tn5-gusA1 has also been used in Xanthomonas campestris (D.W. Gabriel, pers. comm.) and Erwinia amylovora (B.J. Sneath, pers. comm.)]. With $\lambda$ derivatives, the transposition frequency is $\sim 0.5 \times 10^{-5} / \mathrm{PFU}$.

\section{Fusions are regulated in $\mathrm{E}$. coli}

Plasmid pRS475 carrying the E. coli lac operon was mutagenized with $\lambda \Omega:: \operatorname{Tn} 5$-gusA1, and colonies that were white on X-gal (5-bromo-4-chloro-3-indolyl $\beta$-D-galactopyranoside) + IPTG (isopropyl $\beta$-D-thiogalactopyranoside), but deep blue on X-Glc (5-bromo-4-chloro-3-indolyl $\beta$-D-glucuronide) + IPTG, were analyzed. The results (Fig. 3) demonstrate that Tn5-gusA1 fusion inserts are regulated by IPTG, as expected. 


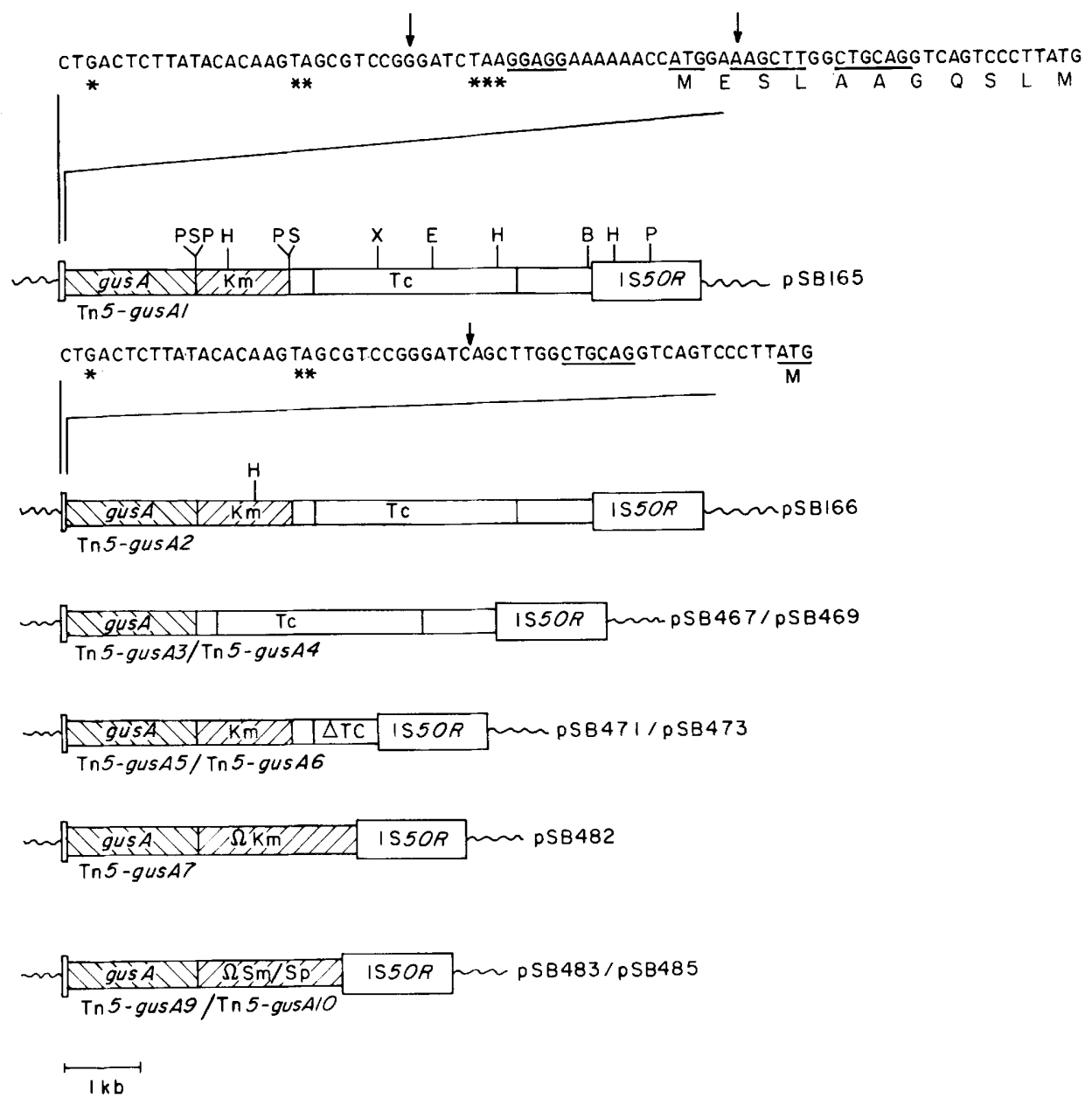

Figure 2. Construction and map of $\operatorname{Tn} 5-$ gus $A$ transposons. Operon and gene fusion transposons are represented by odd and even numbers, respectively. Open and hatched boxes depict Tn5-341:25 DNA (Johnson and Reznikoff 1983) and additional DNA fragments inserted into it, respectively; the wavy line represents ColEl plasmid DNA. The DNA sequence above Tn5-gusA1 shows the gus $A$-coding strand, including the first 25 bp of IS50L fused to a synthetic DNA fragment; the sequence above Tn5-gus 22 includes the first $25 \mathrm{bp}$ of IS50L but not the fragment; the arrow and the asterisks $(*)$ indicate the junction points and the translation terminators, respectively; the Shine-Dalgarno sequence, initiation codon, and HindIII and EcoRI sites are underlined; letters below the sequence represent amino acids; the final ATG shown is the initiation codon of gusA; (E) EcoRI; (H) HindIII; (P) PstI; (S) SalI; (B) BglII; (X) XbaI. Tn5-gusA1 was constructed by ligation of an $\sim 13-\mathrm{kb}$ BamHI-Sall fragment from pRZ465 (ColE1 $\Omega::$ Tn5-341.25) with a synthetic DNA fragment carrying Sau3AI and HindIII cohesive ends (see Experimental procedures), a 1.8-kb HindIII-SauI (gusA gene) fragment from pRAJ260, and a 1.3-kb SalI fragment $\left(\mathrm{Km}^{\mathrm{r}}\right.$, Tn903) from pKAN. Tn5-gusA2 was constructed by ligation of an $\sim 13-\mathrm{kb}$ BamHI-SalI fragment from pRZ465 (with the BamHI site filled in by Klenow polymerase) with a 1.8-kb HindIII-SalI fragment from pRAJ260 (with the HindIII site filled in by Klenow polymerase) and a 1.3-kb SalI fragment from pKAN. Tn5-gusA3 and Tn5-gusA4 were made by deletion of the 1.3-kb SalI $\left(\mathrm{Km}^{\mathrm{r}}\right.$, Tn903) fragments of Tn5-gusA1 and Tn5-gusA2, respectively, and religation. Similarly, Tn5-gusA5 and Tn5-gusA6 were constructed by deletion of the BglII-XbaI (Tcr) fragments of Tn5-gusA1 and Tn5-gusA2, respectively, and religation after filling in of the noncohesive ends with Klenow polymerase. Tn5-gusA7 was made by deletion of the

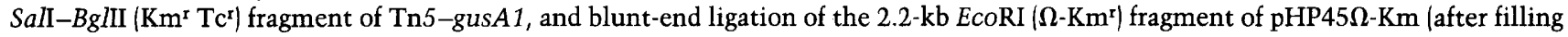

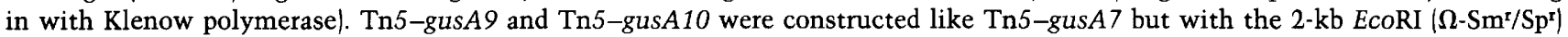
fragment of pHP45 $\Omega$ instead of $\Omega-\mathrm{Km}^{\mathrm{r}}$.

\section{Regulation of nod :: Tn5-gusA fusions in culture by luteolin}

Tn5-gusA fusions were made in nod genes and exchanged to the $R$. meliloti genome. Insertions in nodD1, nodD3, nodI, and $s y r M$ were verified by Southern hybridization (data not shown). Genomic insertions in $\operatorname{nod} B$ and nodC showed no hair curling $\left(\mathrm{Hac}^{-}\right)$, and those in nodI, nodI, nodP, nodQ, and nodE were delayed in nodulation (Nod d), as expected. Genomic insertions in $\operatorname{nod} B, \operatorname{nod} C, \operatorname{nod} E, \operatorname{nodI}, \operatorname{nod} I, \operatorname{nod} P$, and $\operatorname{nod} Q$ were induced manyfold by luteolin (Table 2). However, the same insertions located on plasmid pGMI149 had high basal levels, whereas insertions in nodH, nodE, and nodG located on plasmid pGMI290 had comparatively low expression, which was also not stimulated by luteolin (Table 2). This may be due to syrM, nodD3, or both on pGMI149, which, on a plasmid, have been found 
Table 1. Bacterial strains, plasmids, and phages

\begin{tabular}{|c|c|c|}
\hline Name & Relevant markers & Source \\
\hline \multicolumn{3}{|l|}{ Escherichia coli } \\
\hline $\mathrm{C} 2110$ & polA & lab collection \\
\hline $\mathrm{HB} 101$ & $\begin{array}{l}\text { hsdS20 }\left(r_{B}{ }^{-} m_{B}{ }^{-}\right) \text {recA13 ara-14 } \\
\text { lacY1 galK2 rpsL20 }\left(\mathrm{Sm}^{2}\right) \text { xy1-5 } \\
\text { mtl-1 supE44 }\end{array}$ & Maniatis et al. (1982) \\
\hline JM109 & $\begin{array}{l}\text { recA1 endA1 gyrA96 thi-1 hsdR17 } \lambda^{-} \\
\text {supE44 relA1 } \Delta \text { lac-proAB }\left(\mathbf{F}^{\prime} \text { traD36 }\right. \\
\text { proAB lacI } 1 \text { lacZDM15) }\end{array}$ & $\begin{array}{l}\text { Yanisch-Perron et al. } \\
\text { (1985) }\end{array}$ \\
\hline LE392 & $\begin{array}{l}\mathrm{F}^{-} \text {hsdR514 supE44 supF58 lacY1 galK2 } \\
\text { galT22 metB1 trpR55 } \lambda^{-}\end{array}$ & Maniatis et al. (1982) \\
\hline MM294A & pro-82 thi-1 endA1 hsdR17 supE44 & G.C. Walker \\
\hline MRO & $F^{-}$lac $\Delta X 74$ his & lab collection \\
\hline MT607 & MM294 recA56 & T.M. Finan \\
\hline Q5137 & (גimm434) & lab collection \\
\hline \multicolumn{3}{|c|}{ Rhizobium meliloti } \\
\hline JM83 & JM57 syrM :: Tn5 & $\begin{array}{l}\text { Mulligan and Long } \\
(1985)\end{array}$ \\
\hline JT701 & RM1021 syrM :: Tn5 & $\begin{array}{l}\text { Mulligan and Long } \\
(1985)\end{array}$ \\
\hline $\mathrm{Rm} 1021$ & SU47 str-7 & F. Ausubel \\
\hline $\mathrm{Rm} 1947$ & $\operatorname{Rm} 1021$ fix $:: \operatorname{Tn} 5$ & L. Albright \\
\hline $\mathrm{RmS89}$ & $\mathrm{Rm} 1021$ nodB $:: \operatorname{Tn} 5-$ gus $A 1.3$ & this work \\
\hline $\mathrm{RmS90}$ & Rm1021 nodC :: Tn5-gusA1.9 & this work \\
\hline RmS91 & $\operatorname{Rm} 1021$ nodQ $:: \operatorname{Tn} 5$-gusA1.11 & this work \\
\hline RmS92 & Rml021 nod region IIa (nod) :: Tn5-gusA1.20 & this work \\
\hline $\mathrm{RmS} 94$ & $\mathrm{Rm} 1021 \operatorname{nodQ}:: \operatorname{Tn} 5-$ gus $A 1.54$ & this work \\
\hline RmS95 & $\operatorname{Rm} 1021$ nodE :: Tn5-gusA1.56 & this work \\
\hline $\mathrm{RmS98}$ & Rm1021 nod region IIa (nodI) :: Tn5-gus $A 2.440$ & this work \\
\hline RmS99 & $\mathrm{Rm} 1021 \operatorname{nodP}:: \operatorname{Tn} 5-g u s A 2.475$ & this work \\
\hline $\mathrm{RmS102}$ & $\mathrm{Rml021} \operatorname{nod} C:: \operatorname{Tn} 5-$ gus $A 2.527$ & this work \\
\hline $\mathrm{RmS163}$ & Rml021 syrM :: Tn5-gusA2.444 & this work \\
\hline $\mathrm{RmS225}$ & Rml021 nodD1 :: Tn5-gus 1.17 & this work \\
\hline $\mathrm{RmS227}$ & Rml021 nodD1 :: Tn5-gusA1.35 & this work \\
\hline $\mathrm{RmS} 229$ & $\mathrm{Rm} 1021 \operatorname{nodD} 1:: \operatorname{Tn} 5$-gusA 6.45 & this work \\
\hline $\mathrm{RmS239}$ & $\operatorname{Rm} 1021$ nodD3 $:: \operatorname{Tn} 5-$ gus $A 1.16$ & this work \\
\hline $\mathrm{RmS238}$ & Rm1021 nifH :: Tn5-gusA2.774 & this work \\
\hline $\mathrm{RmS253}$ & $\operatorname{Rm} 1021$ fix $X:: \operatorname{Tn} 5-$ gusA2.98 & this work \\
\hline $\mathrm{RmS255}$ & $\operatorname{Rm} 1021$ nifA :: $\operatorname{Tn} 5-$ gus $A 2.33$ & this work \\
\hline $\mathrm{RmS257}$ & Rml021 fixA :: Tn5-gus $A 2.38$ & this work \\
\hline $\mathrm{RmS261}$ & Rml021 nifB :: Tn5-gusA2.68 & this work \\
\hline $\mathrm{RmS263}$ & $\operatorname{Rm} 1021$ nifD :: $\operatorname{Tn} 5-g u s A 2.71$ & this work \\
\hline $\mathrm{RmS264}$ & $\operatorname{Rm} 1021$ fixB $:: \operatorname{Tn} 5-$ gus $A 2.72$ & this work \\
\hline $\mathrm{RmS268}$ & $\mathrm{Rm1021}$ fix $C:: \operatorname{Tn} 5$-gusA2.104 & this work \\
\hline $\mathrm{RmS318}$ & Rml021 nodI :: Tn5-gusA1.20 syrM :: Tn5 & this work \\
\hline \multicolumn{3}{|l|}{ Plasmids } \\
\hline pGMI149 & pRK290 prime carrying nod genes & Debelle et al. (1986) \\
\hline pGMI290 & pRK290 derivative carrying nodHFEG & $\begin{array}{l}\text { Debelle and Sharma } \\
\text { (1986) }\end{array}$ \\
\hline $\mathrm{pHP} 45 \Omega$ & Carries $\Omega \mathrm{Sm}^{\mathrm{r}} / \mathrm{Spc}^{\mathrm{r}}$ DNA fragment & Fellay et al. (1987) \\
\hline $\mathrm{pHP} 45 \Omega-\mathrm{Km}$ & Carries $\Omega \operatorname{Tn} 5 \mathrm{Km}^{\mathbf{r}}$ DNA fragment & Fellay et al. (1987) \\
\hline pKAN & pBR322 derivative carrying $\operatorname{Tn} 903 \mathrm{Km}^{\mathrm{r}}$ & W.S. Reznikoff \\
\hline pRAJ260 & pEMBL9 derivative carrying gus $A$ & Jefferson et al. (1986) \\
\hline pRK290.720 & pRK290 prime carrying nif and fix genes & Corbin et al. (1982) \\
\hline pRK600 & pRK2013 npt :: $\operatorname{Tn} 9 \mathrm{Cm}^{\mathrm{r}}$ & lab collection \\
\hline pRS475 & pBR322 carrying lac operon & R. Simons \\
\hline pRZ465 & ColE 1 plasmid carrying Tn5-341:25 & $\begin{array}{l}\text { Johnson and } \\
\text { Reznikoff (1983) }\end{array}$ \\
\hline pSB26 & pRK290 prime carrying $8.7-\mathrm{kb} E c o \mathrm{RI}$ fragment with nod $A B C D$ & lab collection \\
\hline pSB165 & Cole $\Omega:: \operatorname{Tn} 5$-gusA1 & this work \\
\hline pSB166 & Cole $\Omega:: \operatorname{Tn} 5-$ gus $A 2$ & this work \\
\hline pSB354 & pRK600 $\Omega:: \operatorname{Tn} 5-$ gus $A 2$ & this work \\
\hline pSB387 & pRK600 $\Omega:: \operatorname{Tn} 5-g u s A 1$ & this work \\
\hline
\end{tabular}


Table 1. Continued

\begin{tabular}{|c|c|c|}
\hline Name & Relevant markers & Source \\
\hline pSB437 & pGMI290 nodH :: Tn5-gus $A 2.437$ & this work \\
\hline pSB445 & pGMI290 nodE :: Tn5-gusA2.445 & this work \\
\hline pSB467 & $\operatorname{ColE} \Omega:: \operatorname{Tn} 5-g u s A 3$ & this work \\
\hline pSB469 & ColE $\Omega:: \operatorname{Tn} 5-$ gus $A 4$ & this work \\
\hline pSB471 & $\operatorname{ColE} \Omega:: \operatorname{Tn} 5-$ gus $A 5$ & this work \\
\hline pSB473 & $\operatorname{ColE} \Omega:: \operatorname{Tn} 5-$ gus $A 6$ & this work \\
\hline pSB482 & ColE $\Omega:: \operatorname{Tn} 5-$ gus $A 7$ & this work \\
\hline pSB483 & $\operatorname{ColE} \Omega:: \operatorname{Tn} 5-$ gus $A 9$ & this work \\
\hline pSB485 & ColE $\Omega$ :: Tn5-gus 10 & this work \\
\hline pSB504 & pRK600 $\Omega:: \operatorname{Tn} 5-g u s A 7$ & this work \\
\hline pVL4 & pBR322 carrying nif $A$ under control of Ptac promoter & M.P.V. Lemley \\
\hline \multicolumn{3}{|l|}{ Phages } \\
\hline$\lambda 58$ & $\lambda$ b221 Oam29 Pam80 & M.S. Fox \\
\hline$\lambda$ SB242 & $\lambda 58 \Omega:: \operatorname{Tn} 5-$ gus $A 1$ & this work \\
\hline$\lambda \mathrm{SB} 247$ & $\lambda 58 \Omega:: \operatorname{Tn} 5-$ gus $A 2$ & this work \\
\hline$\phi \mathrm{M} 12$ & transducing phage of $R$. meliloti & Finan et al. (1984) \\
\hline
\end{tabular}

to cause a high basal level of nodC :: lacZ expression (Mulligan and Long 1989). Our results indicate that the expression of the nodE, nod $G$, nodP, and nod $Q$ genes are also regulated like nodC by $s y r M$ and nodD3. Fusions with nodD1 and nodD3 were constitutive, as expected (Table 2). Comparison of the data for Tn5-gusA1 and Tn5-gusA2 shows that the synthetic Shine-Dalgarno

In situ expression of nod genes

nod:: Tn5-gusA fusions were assayed in three genetic configurations: (1) fusions in $\operatorname{nod} B, \operatorname{nod} C$, nodD1, $\operatorname{nod} D 3$, nodG, nod $H$, nodI, nodI, nodP, or nodQ on plasmid pGMIl49 with a complementing wild-type allele in the genome; (2) fusions in each of these genes (except nodG and nodH) in the genome with the wildtype allele on complementing plasmid pGMI149; and (3) fusions in nodD1, nodD3, nodE, nodI, nodI, nodP, and nodQ in the genome without a complementing wildtype allele. Expression in the different genetic configurations was generally similar, although nodule sections of fusions on the plasmids developed color faster than the meliloti carrying nodG:: Tn5-gusA2 on plasmid pGMI290, which had temporally and spatially aberrant expression that was found to correlate with loss of the sequence is functional in $R$. meliloti. same genomic fusions (Table 3). The exception was $R$.

plasmid (data not shown), even though pGMI290 nodH :: Tn5-gusA2 had typical expression; this was not pursued. The sections of fusions in nodD1 and nodD3 developed color slower than those of other nod fusions. In planta expression of all the nod operon and gene fusions showed the same temporal and spatial pattern in relation to the stages of alfalfa nodule development, illustrated for nodC :: Tn5-gusA2.527 in Figure 4.

Expression on the surface of root hairs and of the nodule cortex (Fig. $4 A, B$ ) By 36 to $48 \mathrm{hr}$ after inoculation, nod :: Tn5-gusA fusions were expressed in bacteria located $\sim 0.5-1 \mathrm{~cm}$ away from the root tip. At 3-6 days post inoculation (dpi), expression was not distributed evenly over the length of the root but was scattered randomly with a slight preference for the point of emergence of secondary roots. By 6-7 dpi, small nodule-like structures began appearing, and expression was seen on the root hairs and on the surface of the nodule cortex. In some cases, there was a single spot at the tip of the nodule; in others, several spots were scattered over the nodule surface. Up to 3 days after nodule emergence (10 dpi), expression was limited to several peripheral cells of the nodule cortex. Later expression of nod genes in our system compared to others (e.g., Dudley et al. 1987) presumably reflects differences in experimental conditions.

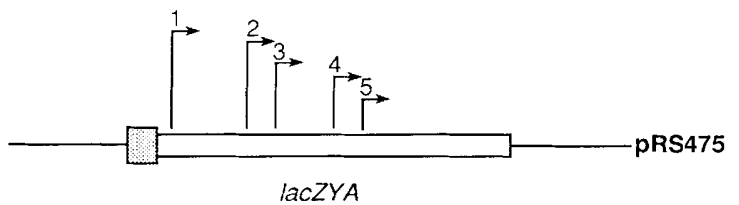

Figure 3. Map of $\operatorname{lacZYA}$ and positions of $\operatorname{Tn} 5-\mathrm{gus} A 1$ insertions. Shaded box, open box, and thin line represent lac promoter region, lacZYA structural genes, and plasmid pRS475 DNA, respectively. Vertical lines on lacZYA show the positions of Tn5-gusA1 insertions. Inducibility of pRS475 lacZ:: Tn5-gusA1 insertions in JM109 by 0.1 mM IPTG is given below the map.

\section{E. coli strain}

JM109 (pRS475)

JM109 (pRS475::Tn5-gusA 1.1) JM109 (pRS475::Tn5-gusA1.4) JM109 (pRS475::Tn5-gusA1.5)

\begin{tabular}{cc}
\multicolumn{2}{c}{ B-glucuronidase units } \\
No IPTG & $\mathbf{0 . 1}$ mM IPTG \\
14 & 14 \\
33 & 1565 \\
35 & 1923 \\
21 & 1817
\end{tabular}


Table 2. Induction of Tn5-gusA fusions by luteolin

\begin{tabular}{|c|c|c|c|}
\hline \multirow[b]{3}{*}{ Strain } & \multirow[b]{3}{*}{ Insertion } & \multicolumn{2}{|c|}{$\beta$-Glucuronidase units } \\
\hline & & & \\
\hline & & $(-)$ & $1+1$ \\
\hline \multicolumn{4}{|c|}{ Genomic insertions } \\
\hline $\mathrm{Rm} 1021$ & & 0 & 0 \\
\hline $\mathrm{RmS} 89$ & $\operatorname{Rm} 1021 \operatorname{nod} B:: \operatorname{Tn} 5-g u s A 1.3$ & 3 & 69 \\
\hline $\mathrm{RmS90}$ & $\mathrm{Rm} 1021 \operatorname{nod} C:: \operatorname{Tn} 5-$ gus $A 1.9$ & 6 & 81 \\
\hline $\mathrm{RmS102}$ & $\mathrm{Rm} 1021 \operatorname{nod} C:: \operatorname{Tn} 5-\operatorname{gus} A 2.527$ & 2 & 132 \\
\hline $\mathrm{RmS98}$ & $\operatorname{Rm} 1021$ nodI $:: \operatorname{Tn} 5$-gus $A 2.440$ & 3 & 92 \\
\hline RmS92 & Rm1021 nodJ :: Tn5-gusA1.20 & 11 & 121 \\
\hline RmS91 & $\mathrm{Rm} 1021 \operatorname{nod} Q^{+}:: \operatorname{Tn} 5-$ gus $A 1.11^{\mathrm{a}}$ & 12 & 124 \\
\hline $\mathrm{RmS94}$ & $\operatorname{Rm} 1021 \operatorname{nod} Q:: \operatorname{Tn} 5-g u s A 1.54$ & 5 & 525 \\
\hline RmS99 & $\operatorname{Rm} 1021$ nodP $:: \operatorname{Tn} 5-$ gusA2.475 & 7 & 71 \\
\hline $\mathrm{RmS95}$ & $\operatorname{Rm} 1021$ nodE :: Tn5-gusA1.56 & 2 & 388 \\
\hline $\mathrm{RmS} 225$ & $\mathrm{Rm} 1021 \operatorname{nodD} 1:: \operatorname{Tn} 5-g u s A 1.17$ & 16 & 19 \\
\hline $\mathrm{RmS227}$ & Rm1021 nodD1 :: Tn5-gusA7.35 & 41 & 42 \\
\hline $\mathrm{RmS239}$ & $\mathrm{Rm} 1021 \operatorname{nodD} 3:: \operatorname{Tn} 5$-gus $A 1.16$ & 5 & 8 \\
\hline $\mathrm{RmS163}$ & Rm1021 syrM :: Tn5-gusA2.444 & 2 & 3 \\
\hline \multicolumn{4}{|c|}{ Insertions on plasmids } \\
\hline $\mathrm{RmS} 32$ & Rm1021 pGMI149 nodB :: Tn5-gusA1.3 & 904 & 897 \\
\hline RmS34 & Rm1021 pGMI149 nodC :: Tn5-gusA1.9 & 1660 & 1870 \\
\hline $\mathrm{RmS68}$ & Rml021 pGMI149 nodC :: Tn5-gusA2.527 & 622 & 820 \\
\hline $\mathrm{RmS60}$ & Rm1021 pGMI149 nodI :: Tn5-gusA2.440 & 964 & 990 \\
\hline $\mathrm{RmS38}$ & Rml021 pGMI149 nodI :: Tn5-gusA1.20 & 1496 & 1942 \\
\hline $\mathrm{RmS35}$ & Rm1021 pGMI149 nodQ :: Tn5-gusA1.11 & 660 & 970 \\
\hline $\mathrm{RmS45}$ & Rm1021 pGMI149 nodQ :: Tn5-gusA1.54 & 212 & 686 \\
\hline $\mathrm{RmS63}$ & Rm1021 pGMI149 nodP :: Tn5-gusA2.475 & 916 & 990 \\
\hline RmS46 & Rm1021 pGMI149 nodE :: Tn5-gusA1.56 & 310 & 612 \\
\hline $\mathrm{RmS184}$ & Rm1021 pGMI290 nodH :: Tn5-gusA2.437 & 41 & 62 \\
\hline $\mathrm{RmS185}$ & Rm1021 pGMI290 nodG :: Tn5-gus $A 2.443$ & 7 & 8 \\
\hline $\mathrm{RmS187}$ & Rm1021 pGMI290 nodE :: Tn5-gusA2.445 & 40 & 45 \\
\hline $\mathrm{RmS37}$ & Rm1021 pGMI149 nodD3 :: Tn5-gusA1.16 & 737 & 796 \\
\hline $\mathrm{RmS} 212$ & $\operatorname{Rm} 1021$ pSB26 nodD1 :: Tn5-gusA1.17 & 784 & 794 \\
\hline $\mathrm{RmS} 214$ & $\operatorname{Rm} 1021$ pSB26 nodD1 :: Tn5-gusA1.35 & 260 & 279 \\
\hline $\mathrm{RmS62}$ & Rm1021 pGMI149 syrM :: Tn5-gusA2.444 & $\begin{array}{l}3 \\
(1)^{\mathrm{b}}\end{array}$ & $\begin{array}{c}4 \\
(1)^{\mathbf{b}}\end{array}$ \\
\hline $\mathrm{RmS183}$ & $\begin{array}{l}\text { Rm1021 fix) }:: \operatorname{Tn} 5 \\
\quad \text { (pGMI149 syrM }:: \operatorname{Tn} 5 \text {-gusA2.444) }\end{array}$ & 3 & 3 \\
\hline $\mathrm{RmS25}$ & Rm1021(pRK290.720 :: Tn5-gusA2.774) & $\begin{array}{c}7 \\
(515)^{\mathrm{b}}\end{array}$ & $\begin{array}{c}12 \\
(941)^{\mathrm{b}}\end{array}$ \\
\hline
\end{tabular}

'Insert is $3^{\prime}$ to nodQ-coding sequence.

bUnits in parentheses represent $\beta$-glucuronidase activity in microaerobic culture (oxygen, $0.4 \%$ )

Table 3. Approximate time required for nodules carrying gusA fusions to show distinct blue color

\begin{tabular}{lc}
\hline Genotype & Time $(\mathrm{min})$ \\
\hline Rm1021 pRK290.720 nifH :: Tn5-gusA2.774 & $5-15$ \\
Rm1021 pRK290.720 fixB :: Tn5-gusA2.72 & $20-30$ \\
Rm1021 pRK290.720 nif $A::$ Tn5-gusA2.33 & $25-35$ \\
Rm1021 pGMI149 nodC :: Tn5-gusA2.527 & $40-60$ \\
Rm1021 pGMI149 nodE :: Tn5-gusA1.56 & $40-60$ \\
Rm1021 pGMI149 nodD1 :: Tn5-gusA7.35 & $180-300$ \\
Rm1021 pGMI149 syrM :: Tn5-gusA2.444 & $180-600$ \\
Rm1021 nifH :: Tn5-gus 2.774 (pRK290.720) & $15-25$ \\
Rm1021 fixB :: Tn5-gusA2.72 (pRK290.720) & $40-60$ \\
Rm1021 nodC :: Tn5-gusA2.527 (pGMI149) & $60-90$ \\
Rm1021 nodE :: Tn5-gusA1.56 (pGMI149) & $60-90$ \\
Rm1021 nodD1 :: Tn5-gusA7.35 (pGMI149) & $480-720$ \\
Rm1021 syrM :: Tn5-gusA2.444 (pGMI149) & $180-600$ \\
\hline
\end{tabular}

Uniform expression within the nodule (Fig. $4 C, D)$ From 10 to $12 \mathrm{dpi}$, expression was visible both in several peripheral cells of the nodule cortex and in cells of the central region proximal to the cortex; slightly older (11-17 dpi) nodules showed more or less uniform expression throughout the central region and a limited area of the nodule cortex.

Polarity of expression toward the nodule meristem (Fig. $4 E-G)$ Between 16 and $22 \mathrm{dpi}$, expression began to show polarity, appearing highest in the nodule meristem and falling off in the central region. From 20 to $25 \mathrm{dpi}$, the region of the nodule between the meristematic region and the central zone, where leghemoglobin is most prominent, showed distinctly lower expression than the meristem, and by $30 \mathrm{dpi}$, expression was limited to the 

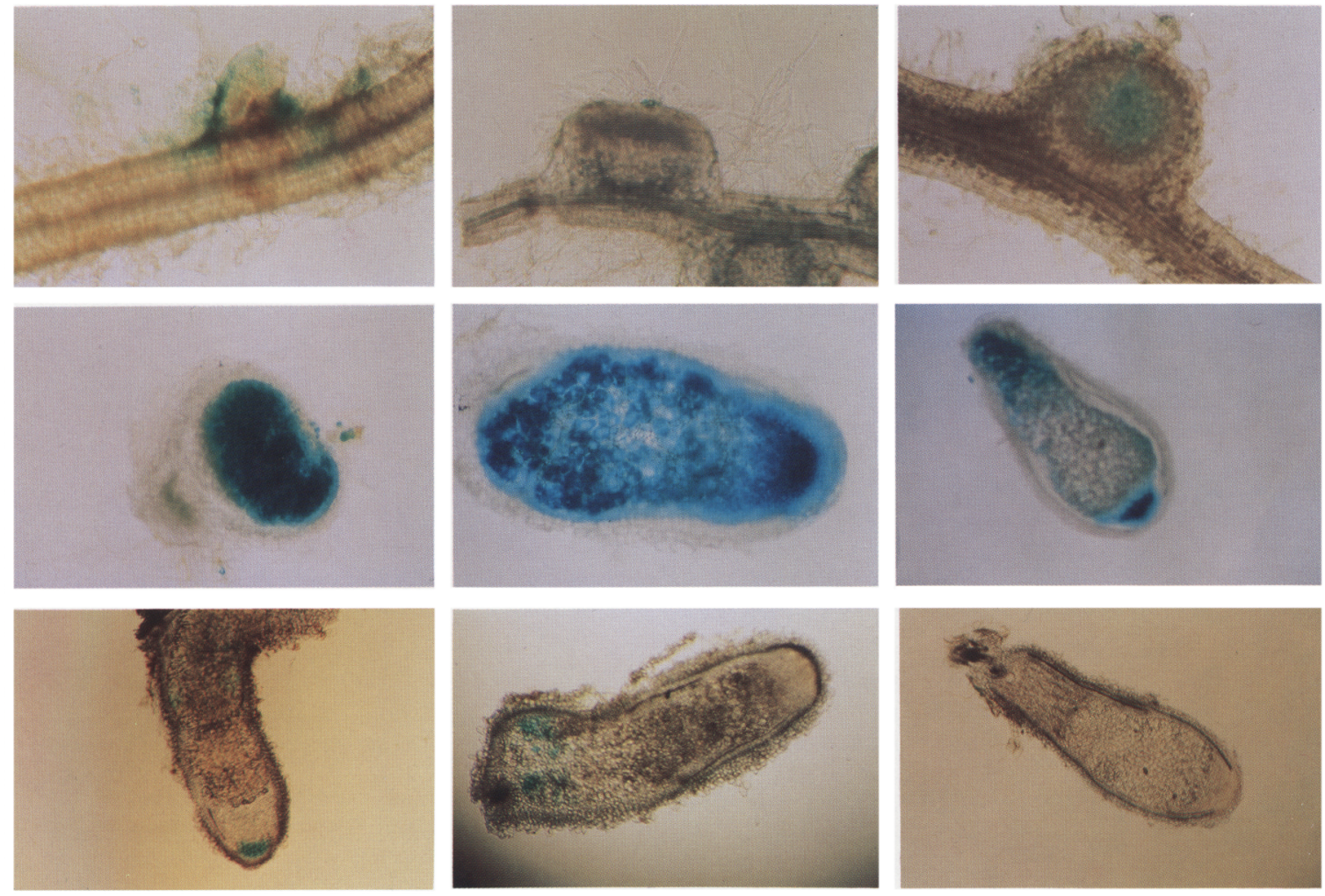

Figure 4. Typical in planta expression of nodC :: Tn5-gusA2.527 [RmS102(pGMI149)] revealed by staining without prior fixation. (A) $5 \mathrm{dpi}$, expression on root hairs and at the point of emergence of a secondary root ${ }_{j}(B) 9$ dpi, expression at the tip of a newly emerging nodule $;(C) 11 \mathrm{dpi}$, expression beginning to appear in the nodule tissue; $(D) 15 \mathrm{dpi}$, expression throughout the nodule except for the uninfected cortex, epidermis, and endodermis; $|E| 17 \mathrm{dpi}$, higher expression in the meristematic zone; $|F| 27 \mathrm{dpi}$, expression high in the meristem and low in the central region (note secondary infection near the root); $(G) 30 \mathrm{dpi}$, expression remaining only in the meristem; $(H) 38 \mathrm{dpi}$, expression mostly gone (note secondary infection and outgrowth of the region proximal to the root); $(I) 45 \mathrm{dpi}$, expression gone.

nodule meristem only. Occasional nodules had two meristems; in some of these, both had equal expression, whereas in others one meristem predominated (not shown). In some nodules, expression was unusually low in the region between the meristem and the central region (not shown).

Disappearance of expression (Fig. 4H-I) In general, expression began disappearing progressively from the meristematic zone between 31 and $37 \mathrm{dpi}$ and had disappeared in most $(\sim 80 \%)$ of the nodules by $45 \mathrm{dpi}$. However, several $(\sim 10 \%)$ of the long, large, pink nodules showed expression in the meristematic zone even after $75 \mathrm{dpi}$. We have some indication that nodD1 fusions may differ slightly from other nod fusions, in having the remaining expression just proximal to the nodule meristem rather than to the meristem itself (data not shown). To test whether disappearance resulted from depletion of nod gene inducers, $42-47$ dpi nodules induced by rhizobia carrying $\operatorname{nod} B, \operatorname{nod} C, \operatorname{nodI}, \operatorname{nod} I, \operatorname{nod} E$, $\operatorname{nod} P$, or nodQ were aseptically sectioned into halves longitudinally; one half was incubated in $\mathrm{H}_{2} \mathrm{O}$, and the other half was incubated in $25 \mu \mathrm{M}$ luteolin in either M9 succinate or M9 sucrose. After a 16-hr incubation at $30^{\circ} \mathrm{C}$, neither half regained expression, even though with younger nodules (26-27 dpi) both halves showed expression under similar conditions, suggesting that inducer depletion is not the reason nod expression disappears.

syrM in concert with nodD3 has been implicated in regulating the expression of nodC in culture (Mulligan and Long 1989). Nevertheless, in planta expression of fusions nodI:: Tn5-gusA1 (genomic, in RmS318), $\operatorname{nodE}:: \operatorname{Tn} 5-$ gusA2 [in JT701 (pSB445)], and nodH :: Tn5-gusA2 [in JT701 (pSB437)] is not altered by the additional mutation $\operatorname{syr} M:: \operatorname{Tn} 5$ (not shown).

\section{Nodules are subject to multiple infection}

Because the nodule cortex shows early expression of nod :: $\operatorname{Tn} 5$-gusA fusions only at the point of infection, 
reinfection of a nodule is easily seen. This is particularly true after 27 dpi (Fig. 4F), when expression is seen mainly in the meristematic zone, and after $42 \mathrm{dpi}$ (Fig. $4 \mathrm{H}$ ), when most of the nodules are not expressing at all. Secondary infection was seen in nodules at all of the stages noted above and was more common in the part of the nodule proximal to the root. Reinfection spread into the previously infected central zone in some cases (Fig. $4 F$ ), and was limited to the nodule cortex in others (Fig. 4H). This result suggests two conclusions: (1) The nodule may continue to secrete nod gene inducer(s) even after expression within the nodule has disappeared; and (2) the previously infected central zone can be infected a second time.

\section{Expression of nod genes per se is not required for nitrogen fixation}

To test nitrogen fixation, duplicate 42 - to 47 -dpi nodules induced by rhizobia carrying fusions in $\operatorname{nod} B$, $\operatorname{nod} C$, nodE, nodI, nodI, nodP, and nodQ were sectioned into halves longitudinally; one half was assayed for acetylene reduction, and the other for nod gene expression by staining with X-Glc. All of the nodule halves reduced acetylene significantly, even though the corresponding halves did not show any staining after $24 \mathrm{hr}$ incubation, as expected /with the exception of nodE and nodI fusions, each of which showed some expression in the nodule meristem in one of the replicates but not the other). Similar results were obtained when 42- to 47-dpi nodules were first assayed for acetylene and then sec- tioned for expression. Thus, nod expression per se does not appear to be required for nitrogen fixation.

\section{nif :: Tn5-gusA and fix :: Tn5-gusA expression in culture}

nif and fix genes are known to be induced under microaerobic conditions either in culture or in the nodule (Ditta et al. 1987; David et al. 1988; Batut et al. 1989). Consistent with this, we found that rhizobia carrying nif or fix fusions formed white or pale blue colonies on X-Glc agar but elicited nodules that stained blue (Fig. 5). Table 2 shows induction of a nifH fusion in microaerobic culture and slight stimulation by luteolin.

\section{In situ expression of nif and fix genes}

Tn5-gusA fusions in nif and fix genes were analyzed in three configurations: (1) genomic fusions with nif $A$, nif $D$, and nifH and with fixA, fix $B$, fix $C$, and fix $X ;(2)$ the same genomic fusions with plasmid pRK290.720, which carries the wild-type allele for all of the genes except nif $B$ and nif $K$; and (3) plasmid fusions with nif $A$, nif $B$, nifH, nifD, and nifK and fix $A$, fix $B$, fix $C$, and fix $X$, complemented by the genomic wild-type allele. In contrast with the nod fusions (Fig. 4), in situ expression of fusions with nif and fix genes (Fig. 5) showed a different pattern, illustrated for nifH :: Tn5-gusA2.774 in Figure 5. (1) At 11-12 dpi, when the central region had the pink color of leghemoglobin, expression began appearing throughout the nodule, except in the meristematic zone (Fig. 5A-C). (2) After $\sim 37$ dpi, most Fix $^{+}$nodules
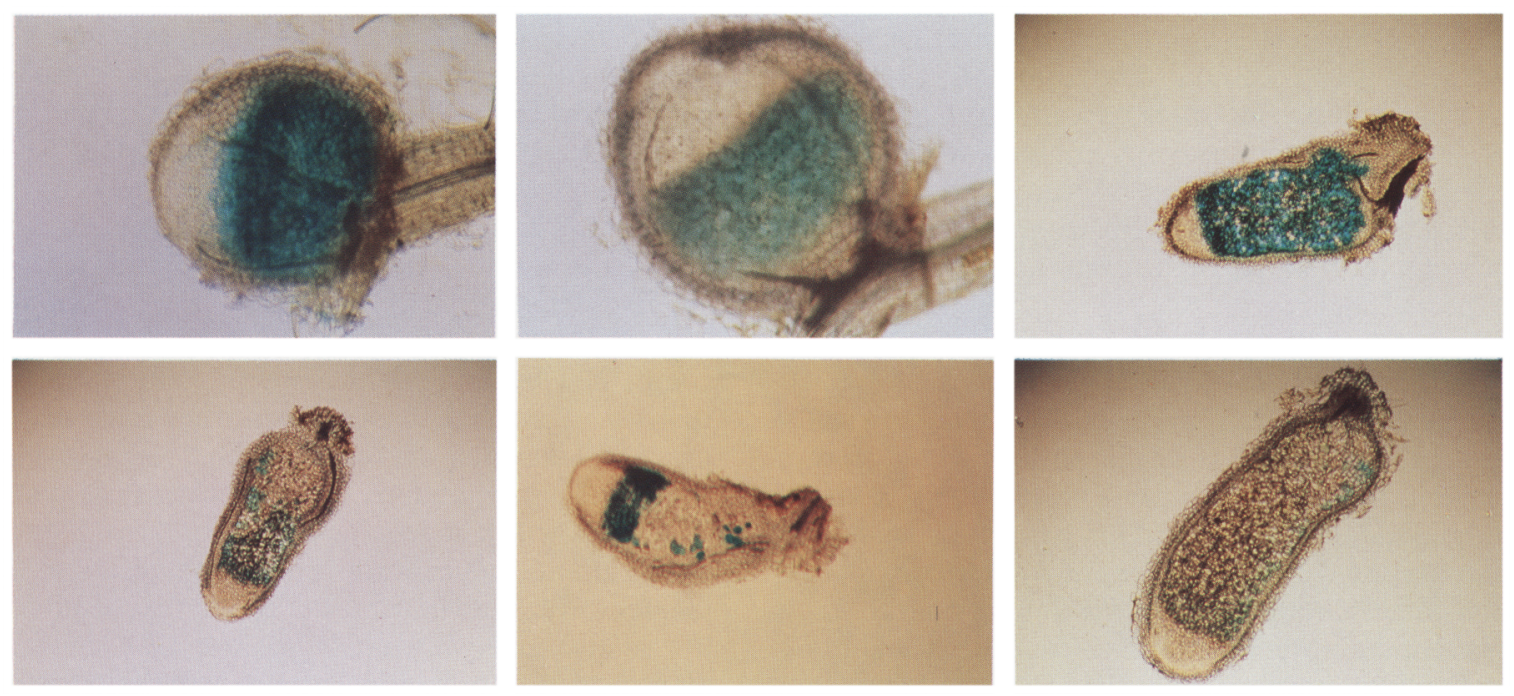

Figure 5. Typical in planta expression of nifH :: Tn5-gusA2.774 [RmS238(pRK290.720)] revealed by staining without prior fixation. (A) $12 \mathrm{dpi}$; $(B) 15 \mathrm{dpi}$; $(C) 17 \mathrm{dpi}$, expression in the central zone of the nodule (strongest proximal to the meristem); $(D) 30 \mathrm{dpi}$, expression disappearing in the central zone distal to the meristem; $(E) 37 \mathrm{dpi}$, expression remaining in the central zone only proximal to the meristem; $(F) 55$ dpi, expression gone. 
showed expression only in the central region proximal to the meristem, presumably because of senescence of the distal region (Fig. 5D,E). Fusions that were Fix ${ }^{-}$(i.e., those not complemented by the wild-type allele) began to lose distal expression earlier, at $\sim 22 \mathrm{dpi}$, presumably because of earlier senescence. (3) By $\sim 55 \mathrm{dpi}$, all nodules had very low expression (Fig. 5F).

\section{Expression of syrM}

Expression of a syrM fusion was studied in the same three configurations as above. Expression in either aerobic or microaerobic culture was low (Table 2). The in situ expression pattern of the syr $M$ fusion was like that of the nif and fix fusions, although staining was slower (Table 3). A doubly mutant strain carrying pGMI149 syrM :: Tn5-gusA2, as well as fixJ :: Tn5, had the same temporal expression pattern (although at $\sim 22 \mathrm{dpi}$, most of the nodules showed expression only in the central region of the nodule proximal to the meristem, as with other Fix ${ }^{-}$strains; see abovel. Thus, although we have not tested other mutations in combination with fix I, expression of syrM, in contrast to that of other genes expressed late (nif and fix), appears not to be regulated by fix $L J$.

\section{Discussion}

In this paper we describe the construction and use of Tn5-gusA promoter/probe transposons that fuse the gus $A$ reporter gene either transcriptionally or translationally with a target promoter. In situ assay of gus $A$ gene and operon fusions has proved to be of enormous value for the study of gene expression in transgenic plants, particularly with regard to cell and tissue specificity (Jefferson 1987; Jefferson et al. 1987; Willmitzer 1988). Similarly, Tn5-gus $A$ fusions, which can be constructed in bacteria in vivo by simple transpositional mutagenesis, allow in situ monitoring of target gene expression during plant/bacterial interaction.

We have used these constructs to study the expression of $R$. meliloti genes involved in symbiosis with alfalfa during organogenesis of nitrogen-fixing root nodules. Our results delineate the overall patterns of expression of 21 such symbiotic genes and reveal a number of new and unexpected aspects.

The principal result is that each of the 21 genes can be assigned to one of only two overall patterns of temporal and spatial expression during alfalfa root nodule development. The Nod pattern is displayed by all nod genes studied (nodB, nodC, nodD1, nodD3, nodE, nodG, nod $H$, nodI, nodI, nodP, and nodQl. This pattern consists of expression first on the root surface and nodule cortex 136 $\mathrm{hr}$; $10 \mathrm{dpi}$ ); next throughout the developing nodule, including the nodule meristem (10-17 dpi); then mainly in the nodule meristem, progressively falling off distally through the central region toward the root (16-41 dpi); and, finally, little, if at all, throughout, except in several unusual nodules $(42-75 \mathrm{dpi})$. In contrast is the Nif pattern, displayed by all nif genes studied (nif $A$, nif $B$, nifD, nif $H$, and nifK), all fix genes studied (fix $A, f i x B, f i x C$, and fixX), and $s y r M$. This pattern consists of expression that begins only later $(\sim 10 \mathrm{dpi})$, first throughout the central region but strongest in the "active symbiotic zone" just behind the nodule meristem, where leghemoglobin is most prominent, and not at all in the meristem itself (11-35 dpi); then behind the meristem but progressively falling off distally through the rest of the central region (35-55 dpi); and, finally, little, if at all, throughout (55-75 dpi).

Others have shown that genes of the Nod pattern are regulated by the NodD1, NodD2, and/or NodD3 products, which induce the remaining nod genes in response to plant flavonoids (Mulligan and Long 1985, 1989; Peters et al. 1986; Spaink et al. 1987). Likewise, genes of the Nif pattern are regulated by the FixLJ/NifA/ FixK cascade, which induces the remaining nif and fix genes in response to low oxygen tension (Ditta et al. 1987; David et al. 1988, Batut et al. 1989). Our results extend this work by revealing some of the temporal and spatial dimensions of these regulatory interactions.

\section{Nod pattern}

In cylindrical nodules like those of alfalfa, the meristem located at the nodule tip contains small nonvacuolate actively proliferating cells. These are usually considered to be uninfected, with infection accompanying a transition from meristematic to the larger vacuolate nitrogenfixing cells (e.g., Newcomb 1981). A striking and unexpected component of the Nod pattern is expression of all $R$. meliloti nod genes in the meristematic zone. This has not been reported previously. Our data do not show whether invading bacteria have infected the meristematic cells or are only present between them. Because morphological studies have not revealed bacteria within meristematic cells, the latter may be more likely.

The timing of nod gene expression and its prevalence in the meristem is consistent with evidence that the products of $\operatorname{nod} A$ and $\operatorname{nod} B$ appear to stimulate cell growth (Schmidt et al. 1988), and other aspects of the Nod pattern show this correlation as well. Thus, the later disappearance of nod gene expression coincides in time with cessation of nodule elongation; unusual nodules in which nod expression continues at late times are also unusually long; late secondary infection, which normally occurs at the base of the nodule, is usually accompanied by a small outgrowth; and young nodules that abort and fail to develop further have no nod expression (data not shown). Continued synthesis of nod gene products, therefore, seems necessary for continued nodule growth and development.

The later disappearance of nod gene expression, which incidentally implies turnover of enzyme expressed earlier, is also unexpected. Disappearance is not due to depletion of nod inducers, because expression cannot be restored with luteolin. This is also shown by the ability of rhizobia expressing nod to reinfect nodules in which prior nod expression has already ceased, although we cannot tell whether the individual cells in a region in- 
fected secondarily are the same ones that were infected previously. Disappearance could reflect a specific signal, which may be part of the nodule cells senescence program but cannot reflect general cell death because genes of the Nif pattern continue to be expressed at this time. Interestingly, the early pea nodulin ENOD2, which seems to be induced by a signal based on nod expression (Govers et al. 1986; Dickstein et al. 1988), also declines later in nodule development (Franssen et al. 1987). Such observations remain to be reconciled with indirect evidence suggesting effects of nod expression later in development on exo gene function in R. meliloti (Klein et al. 1988) and on induction of vetch nodulins by Rhizobium leguminosarum (Nap et al. 1989).

In any case, our results show the same Nod pattern for the regulatory nodD1 and nodD3 genes as for the other, presumed structural nod genes, suggesting that the nodD genes, themselves, are subject to regulation in planta as well. Whether this regulation is relatèd to the regulation of nodD found in derivatives of $R$. meliloti strain Rm41 but not of strain SU47 (Kondorosi et al. 1989), which was used here, is not yet clear.

\section{Nif pattern}

The Nif pattern of expression differs markedly from the Nod pattern, both temporally and spatially. Temporally, expression takes place considerably later in the Nif than in the Nod pattern, as has long been known for the genes encoding nitrogenase (Bergersen and Goodchild 1973; Long 1989|. Spatially, expression in the Nif pattern, unlike the Nod pattern, is completely absent from the meristematic zone but is most prominent just behind the meristem, like expression of leghemoglobin (Bergersen and Goodchild 1973; Verma et al. 1979), upon which nitrogenase function depends. Although expression of Nif pattern genes occurs later and is known to be regulated (by FixLJ-NifA), it does not seem to depend on continued expression of Nod pattern genes per se, as it continues well after nod expression has disappeared. As in the case of Nod pattern gene expression, Nif pattern expression disappears very late in nodule development, as a result of either regulation or general cell senescence.

Although little is known about the symbiotic role of $s y r M$, our results for this gene are surprising. $s y r M$ has been implicated in the regulation of nod and exo genes (Mulligan and Long 1989), both of which are expressed early. Yet, we find that mutation of $s y r M$ does not detectably affect in situ expression of Nod pattern genes; that expression of $s y r M$, itself, follows the later Nif pattern rather than the early Nod pattern, but that unlike other Nif pattern genes (nif, fix), expression of syrM depends neither on microaerobic conditions nor on fixJ. Thus, syrM remains a puzzle.

\section{Final comments}

Our findings support the well-established notion of nodule organogenesis as a coordinated developmental pathway involving both symbiotic partners. Temporally, rhizobial symbiotic gene expression resembles that of other prokaryotic sequential differentiated systems, such as sporulation and phage growth, particularly in its dependence on regulatory cascades that are now being elucidated. The in situ results clearly indicate considerable and complex signaling between plant cells and bacteria, regarding, for example, expression in the meristematic zone and disappearance late in nodule development.

These studies illustrate the utility of the Tn5-gusA transposons that we have constructed. Transposon fusions should continue to be useful in further unraveling of the regulatory interactions in nodule organogenesis. They should be similarly useful for studying other prokaryote/eukaryote systems, such as plant microbial pathogenesis. Finally, transposon mutagenesis in bacteria in vivo should simplify construction of fusions in cloned plant genes for subsequent introduction into transgenic plants.

\section{Experimental procedures}

\section{Bacterial strains, plasmids, and media}

Bacterial strains, plasmids, and phages are described in Table 1. Unless indicated otherwise, media and drug concentrations were as described by Finan et al. (1985) and Glazebrook and Walker (1989). For R. meliloti, M9 medium (Miller 1972) supplemented with $2 \mu \mathrm{g} / \mathrm{ml}$ biotin, $0.2 \%$ (wt/vol) glucose or sucrose, $20 \mu \mathrm{g} / \mathrm{ml} \mathrm{X-Glc,} \mathrm{or} 20 \mu \mathrm{g} / \mathrm{ml}$ MUG (4-methyl umbelliferyl glucuronide) was used for assay of $\beta$-glucuronidase on plates. For E. coli, both M9 and LB supplemented with $20 \mu \mathrm{g} / \mathrm{ml}$ $\mathrm{X}$-Glc were used.

\section{Genetic techniques}

$\lambda$ lysates were prepared according to de Bruijn and Lupski (1984). Transduction with $\phi M 12$ was as described in Finan et al. (1984). pGMI149 and various other plasmid derivatives were transferred from one strain to another by triparental mating with pRK600. Tn5 insertions in pRK290 plasmid derivatives were exchanged to the $R$. meliloti genome by introduction of the incompatible plasmid pPHIJI (Ruvkun et al. 1982).

\section{Plant and nodulation assays}

Medicago sativa cv. Iroquois (Agway, Inc., Plymouth, Indiana) seeds were grown and inoculated as described by Glazebrook and Walker (1989). Root hair curling was examined according to Debelle et al. (1986). Date of emergence of each nodule induced by $R$. meliloti carrying a Tn5-gusA fusion was marked for temporal studies of expression. Nitrogen fixation was determined by plant growth and, in some cases, by acetylene reduction (Ruvkun and Ausubel 1981). Bacteria were recovered from nodules as described by Glazebrook and Walker (1989).

\section{Spectrophotometric and histochemical enzyme assays}

For $\beta$-glucuronidase enzyme assay, $R$. meliloti was grown in M9 supplemented with $0.4 \%$ (wt/vol) sodium succinate and 2 $\mu \mathrm{g} / \mathrm{ml}$ biotin to early $\log$ phase $\left(\mathrm{OD}_{600}=0.05\right.$ to 0.1$)$, and luteolin was then added to a $10 \mu \mathrm{M}$ final concentration. $\beta$-Glucuronidase was assayed according to Jefferson et al. (1986). For microaerobic studies, bacteria grown to early log phase were divided into four tubes; two of the tubes were then stoppered 
tightly, flushed for $10 \mathrm{~min}$ with nitrogen, and injected with air to give the desired oxygen concentration; all four tubes were then shaken at $30^{\circ} \mathrm{C}$ for $1 \mathrm{hr}$, and luteolin was added to $10 \mu \mathrm{M}$ in one aerobic and one microaerobic tube; $1-\mathrm{ml}$ aliquots were assayed for enzyme activity.

For histochemical assay of $\beta$-glucuronidase, nodules were embedded in $7 \%$ agarose and sectioned with a Sorval TC-2 tissue sectioner (DuPont Instruments). For fixation, nodules or nodule sections were incubated in $2 \%$ paraformaldehyde for 5 min at room temperature, washed several times with $50 \mathrm{~mm}$ phosphate buffer ( $\mathrm{pH} 7)$, and stained. For staining, 100- to 250$\mu \mathrm{m}$ sections, as well as young nodules and roots, were incubated with $20 \mu \mathrm{g} / \mathrm{ml} \mathrm{X-Glc}+0.02 \%$ SDS in $50 \mathrm{~mm}$ phosphate buffer $\left(\mathrm{pH}\right.$ 7) with or without prior fixation at $30^{\circ} \mathrm{C}$ from $20 \mathrm{~min}$ to several hours and examined in the light microscope.

\section{Construction of Tn5-gusA delivery vehicles}

$\lambda \operatorname{Tn} 5$-gusA delivery vehicles were made as follows: A lysate of $\lambda b 221$ cI857 Oam29 Pam90 (deleted for att $\lambda$ ) was made on LE392 (pSB165). $\lambda$ derivatives carrying the transposon were isolated by infection of Q5137 (lysogenic for $\lambda$ imm 434 to provide homology for $\lambda$ integration/ at $\mathrm{MOI}=5$, and $\mathrm{Km}^{\mathrm{r}}$ and $\mathrm{Tc}^{\mathrm{r}}$ colonies were selected at $30^{\circ} \mathrm{C}$. Colonies that grew at $30^{\circ} \mathrm{C}$ but not at $42^{\circ} \mathrm{C}$ (because of $\lambda$ prophage induction) were used to make phage lysates. These colonies were then screened for plaques having imm $\lambda$ and giving turbid centers at $30^{\circ} \mathrm{C}$ that contained $\mathrm{Km}^{2}$ bacteria, which carried prophage $\lambda b 221$ c1857 Oam29 Pam80 $\Omega$ :: Tn5-gusA2 was constructed similarly with LE392 (pSB166).

pRK600 $\Omega::$ Tn5-gusA1 derivatives were constructed by triparental mating of LE392 (pSB165), C2110, and MT607 (pRK600). Selected Nalr $\mathrm{Km}^{\mathrm{r}}$ colonies carried a Tn5-gusA1 insertion in the C2110 chromosome, as neither pRK600 nor pSB165 can replicate in this polA host. These colonies were then mated triparentally with HBl01 and MT607 (pRK600). HB101 (pRK600 $\Omega:: \operatorname{Tn} 5$-gusA1) colonies were selected as $\mathrm{Sm}^{\mathrm{r}}$ $\mathrm{Tc}^{\mathrm{r}} \mathrm{Km}^{\mathrm{r}} \mathrm{Cm}^{\mathrm{r}}$, and the derivative that gave highest frequency of Tn5-gusA1 transfer into $R$. meliloti was chosen for further work. Other pRK600 $\Omega:: \operatorname{Tn} 5$-gusA derivatives were constructed similarly.

\section{Tn5-gusA mutagenesis}

$\lambda \operatorname{Tn} 5-$ gus $A$ mutagenesis was performed as described by de Bruijn and Lupski (1984). Plasmids to be mutagenized were transformed into $E$. coli MRO, and colonies were selected on a high concentration of $\mathrm{Km}(200 \mu \mathrm{g} / \mathrm{mI})$ at $30^{\circ} \mathrm{C}$ to favor preferential insertion into the high copy plasmid. Plasmids isolated from these cells were transformed into $E$. coli and insertions were localized by restriction analysis. For delivery by pRK600, C2110 harboring the target plasmid was mated with $E$. coli (pRK600 $\Omega:: \operatorname{Tn} 5$-gus A), and the mutagenized C2110 population was analyzed as above.

For isolation of $\operatorname{Tn} 5$-gus $A$ insertions in nod genes, mutagenized $E$. coli populations grown on $\mathrm{Km}(200 \mu \mathrm{g} / \mathrm{ml})$ and Tc $(20$ $\mu \mathrm{g} / \mathrm{ml}$ ) were mated en masse to $R$. meliloti, and colonies on M9 sucrose $[0.2 \%(\mathrm{wt} / \mathrm{vol})]$ plus $10 \mu \mathrm{M}$ luteolin that were $\mathrm{Tc}^{\mathrm{r}}(10$ $\mu \mathrm{g} / \mathrm{ml})$ and $\mathrm{Nm}^{\mathrm{r}}(100 \mu \mathrm{g} / \mathrm{ml})$ and blue on X-Glc $(20 \mu \mathrm{g} / \mathrm{ml})$ were analyzed further.

Insertions in nif and fix genes were obtained by two methods. In the first method, a mutagenized population of pRK290.720 was transformed into JM109 (pVL4), in which nifA is under the control of the Ptac promoter. Transformants that were deep blue on M9 X-GLc with $1 \mathrm{~mm}$ IPTG, but pale blue without IPTG, should have insertions in nif or fix genes; of several such insertions, one (nifH :: Tn5-gusA2) was analyzed further. $R$. meliloti carrying this insertion on a plasmid formed very pale blue colonies on M9 X-Glc agar but induced nodules that stained deep blue with X-Glc. However, induction of nifA with IPTG made the strain grow slowly. Consequently, a second method was used, in which 100 mutagenized populations of $E$. coli carrying pRK290.720 were mated into $R$. meliloti; from each mating, pale blue colonies were purified and inoculated on alfalfa individually. Of these colonies, 34 induced nodules that stained blue with X-Glc. Plasmids were isolated from these colonies, and the insertions were analyzed.

\section{Recombinant DNA techniques}

Plasmid isolation, DNA restriction with various enzymes, dephosphorylation of DNA ends, and purification of DNA fragments by electroelution, ligation, and transformation were all done according to Maniatis et al. (1982). Complementary DNA fragments with sequences 5'-GATCTAAGGAGGAAAAAACCATGGAA and 5'-AGCTTTCCATGGTTTTTTCCTCCTTA, which include a third translation terminator, a Shine-Dalgarno sequence with properly spaced ATG (underlined), and BamHIand HindIII-compatible single-stranded ends, were custom synthesized at the Whitehead Institute (MIT).

\section{Acknowledgments}

We thank Ann Hirsch for loan of the tissue sectioner, and Richard Jefferson and David Hirsh for pRAJ260. This work was supported by grant GM36370 from the National Institutes of Health.

\section{References}

Aguilar, O.M., H. Reilander, W. Arnold, and H. Puhler. 1987. Rhizobium meliloti nif $N$ (fix F) gene is part of an operon reg. ulated by a nif $A$-dependent promoter and codes for a polypeptide homologous to the nifK gene product. $/$. Bacteriol. 169: $5393-5400$.

Batut, J., M.L. Daveran-Mingot, M. David, J. Jacobs, A.M. Garnerone, and D. Kahn. 1989. fixK, a gene homologous with $f n r$ and crp from Escherichia coli, regulates nitrogen fixation genes both positively and negatively in Rhizobium meliloti. EMBO I. 8: 1279-1286.

Bergersen, F.J. and Goodchild. 1973. Cellular location and concentration of leghemoglobin in soybean root nodules. Aust. I. Biol. Sci. 26: 741-756.

Buikema, W.J., W.W. Szeto, P.V. Lemley, W.H. Orme-Johnson, and F.M. Ausubel. 1985. Nitrogen fixation specific regulatory genes of Klebsiella pneumoniae and Rhizobium meliloti share homology with the general nitrogen regulatory gene ntrC of Klebsiella pneumoniae. Nucleic Acids Res. 13: 4539-4555.

Buikema, W.J., J.A. Klingensmith, S.L. Gibbons, and F.M. Ausubel. 1987. Conservation of structure and location of Rhizobium meliloti and Klebsiella pneumoniae nifB genes. $J$. Bacteriol. 169: 1120-1126.

Callaham, D.A. and J.G. Torrey. 1981. The structural basis for infection of root hairs of Trifolium repens by Rhizobium. Can. J. Bot. 59: 1647-1664.

Cervantes, E., S.B. Sharma, F. Maillet, J. Vasse, G. Truchet, and C. Rosenberg. 1989. The Rhizobium meliloti host range nodQ gene encodes a protein which shares homology with translation elongation and initiation factors. Mol. Microbiol. 3: 745-755. 
Corbin, D., G. Ditta, and D.R. Helinski. 1982. Clustering of nitrogen fixation (nif) genes in Rhizobium meliloti. I. Bacteriol. 149: 221-228.

David, M., M.L. Daveran, J. Batut, A. Dedieu, O, Domergue, J. Ghai, C. Hertig, P. Boistard, and D. Kahn. 1988. Cascade regulation of nif gene expression in Rhizobium meliloti. Cell 54: $671-683$.

Debelle, F. and S.B. Sharma. 1986. Nucleotide sequence of Rhizobium meliloti RCR2011 genes involved in host specificity of nodulation. Nucleic Acids Res. 14: 7453-7472.

Debelle, F., C. Rosenberg, J. Vasse, F. Maillet, E. Martinez, J. Denarie, and G. Truchet. 1986. Assignment of symbiotic developmental phenotype to common and specific nodulation (nod) genetic loci of Rhizobium meliloti. I. Bacteriol. 168: $1075-1086$.

de Bruijn, F.J. and J.R. Lupski. 1984. The use of transposon Tn5 mutagenesis in the rapid generation of correlated physical and genetic maps of DNA segments cloned into multicopy plasmids-a review. Gene 27: 131-149.

Dickstein, R., T. Bisseling, V.N. Reinhold, and F. Ausubel. 1988. Expression of nodule-specific genes in alfalfa root nodules blocked at an early stage of development. Genes Dev. 2: 677-687.

Ditta, G., E. Virts, A. Palomares, and D. Kim. 1987. The nifA gene of Rhizobium meliloti is oxygen regulated. J. Bacteriol. 169: 3217-3233.

Dudley, M.E., T.W. Jacobs, and S.R. Long. 1987. Microscopic studies of cells divisions induced in alfalfa roots by Rhizobium meliloti. Planta 171: 289-301.

Dylan, T., L. Ielpi, S. Stanfield, L. Kashyap, C. Douglas, M. Yanofsky, E. Nester, D.R. Helinski, and G. Ditta. 1986. Rhizobium meliloti genes required for nodule development are related to chromosomal virulence genes in Agrobacterium tumefaciens. Proc. Natl. Acad. Sci. 83: 4403-4407.

Earl, C.D., C.W. Ronson, and F.M. Ausubel. 1987. Genetic and structural analysis of the Rhizobium meliloti fixA, fix $B$, fix $C$, and fixX genes. J. Bacteriol. 169: 1127-1136.

Evans, I.J. and J.A. Downie. 1986. The nodI gene product of Rhizobium leguminosarum is closely related to ATPbinding bacterial transport proteins; nucleotide sequence analysis of the nodI and nodI genes. Gene 43: 95-101.

Faucher, C., S. Camut, J. Denaire, and G. Truchet. 1989. The nodH and nodQ host range genes of the Rhizobium meliloti behave as avirulence genes in $R$. leguminosarum bv. viciae and determine changes in the production of plant-specific extracellular signals. Mol. Plant-Microbe Interact. 2: 291300.

Fellay, R., J. Frey, and H. Krisch. 1987. Interposon mutagenesis of soil and water bacteria: A family of DNA fragments designed for in vitro insertional mutagenesis of gram-negative bacteria. Gene 52: 147-154.

Finan, T.M., E. Hartwieg, K. LeMieux, K. Bergman, G.C. Walker, and E.R. Signer. 1984. General transduction in Rhizobium meliloti. J. Bacteriol. 159: 120-124.

Finan, T.M., A.M. Hirsch, J.A. Leigh, E. Johansen, G.A. Kuldau, S. Deegan, G.S. Walker, and E.R. Signer. 1985. Symbiotic mutants of Rhizobium meliloti that uncouple plant from bacterial differentiation. Cell 40: 869-877.

Fisher, R.F., J. Tu, and S.R. Long. 1985. Conserved nodulation genes in Rhizobium meliloti and Rhizobium trifolii. Appl. Environ. Microbiol. 49: 1432-1435.

Franssen, H.J., J.P. Nap, T. Gloudemans, W. Stiekema, H. Van Dam, F. Govers, J. Louwerse, A. Van Kammen, and T. Bisseling. 1987. Characterization of cDNA for nodulin-75 of soybean: A gene product involved in early stages of root nodule development. Proc. Natl. Acad. Sci. 84: 4495-4499.
Glazebrook, J. and G.C. Walker. 1989. A novel exopolysaccharide can function in place of the calcoflour-binding exopolysaccharide in nodulation of alfalfa by Rhizobium meliloti. Cell 56: 661-672.

Govers. F., M. Moerman, J.A. Downie, P. Hooykaas, H.J. Franssen, J. Louwerse, A. van Kammen, and T. Bisseling. 1986. Rhizobium nod genes are involved in inducing an early nodulin gene. Nature 323: 564-566.

Gyorgypal, Z., N. Iyer, and A. Kondorosi. 1988. Three regulatory nodD alleles of diverged flavonoid-specificity are involved in host-dependent nodulation by Rhizobium meliloti. Mol. Gen. Genet. 212: 85-92.

Hertig, C., R.Y. Li, A.N. Louarn, A.M. Garnerone, M. David, J. Batut, D. Kahn, and P. Boistard. 1989. Rhizobium meliloti regulatory gene $f i x J$ activates transcription of $R$. meliloti nif $A$ and fixK genes in Escherichia coli. I. Bacteriol. 171: $1736-1738$.

Honma, M.A. and F.M. Ausubel. 1987. Rhizobium meliloti has three functional copies of the nodD symbiotic regulatory genes. Nucleic Acids Res. 84: 8558-8562.

Jefferson, R.A. 1987. Assaying chimeric genes in plants: The GUS gene fusion system. Plant Mol. Biol. Rep. 5: 387-405.

Jefferson, R.A., S.M. Burgess, and D. Hirsh. 1986. $\beta$-Glucuronidase from Escherichia coli as a gene-fusion marker. Proc. Natl. Acad. Sci. 83: 8447-8451.

Jefferson, R.A., T.A. Kavanagh, and M.W. Bevan. 1987. GUS fusions: $\beta$-Glucuronidase as a sensitive and versatile gene fusion marker in higher plants. EMBO J. 6: 3901-3907.

Johnson, R.C., and W.A. Reznikoff. 1983. DNA sequences at the ends of transposon $\mathrm{Tn} 5$ required for transposition. $\mathrm{Na}$ ture 304: 280-282.

Kahn, D., M. David, O. Domergue, M.L. Daveran, J. Ghai, P.R. Hirsch, and J. Batut. 1989. Rhizobium meliloti fixGHI sequence predicts involvement of a specific cation pump in symbiotic nitrogen fixation. J. Bacteriol. 171: 929-939.

Keller, M., P. Muller, R. Simon, and A. Puhler. 1988. Rhizobium meliloti genes for exopolysaccharide synthesis and nodule infection located on megaplasmid 2 are actively transcribed during symbiosis. Mol, Plant-Microbe Interact. 1: 267-274.

Klein, S., G.C. Walker, and E.R. Signer. 1988. All nod genes of Rhizobium meliloti are involved in alfalfa nodulation by exo mutants. J. Bacteriol. 170: 1003-1006.

Klipp, W., H. Reilander, A. Schluter, R. Krey, and A. Puhler. 1989. The Rhizobium meliloti $f d x N$ gene encoding a ferredoxin-like protein is necessary for nitrogen fixation and is cotranscribed with nifA and nifB. Mol. Gen. Genet. 216: $293-302$.

Kondorosi, E., Z. Banfalvi, and A. Kondorosi. 1984. Physical and genetic analysis of a symbiotic region of Rhizobium meliloti: Identification of nodulation genes. Mol. Gen. Genet. 193: $445-452$.

Kondorosi, E.,, J. Gyuris, J. Schmidt, M. John, E. Duda, B. Hoffman, J. Schell, and A. Kondorosi. 1989. Positive and negative control of nod gene expression in Rhizobium meliloti is required for optimal nodulation. EMBO J. 8: 13311340.

Long, S.R. 1989. Rhizobium-legume nodulation: Life together in the underground. Cell 56: 203-214.

Long, S., J.W. Reed, J. Himawan, and G.C. Walker. 1988. Genetic analysis of a cluster of genes required for synthesis of the calcofluor-binding exopolysaccharide of Rhizobium meliloti. J. Bacteriol. 170: 4239-4248.

Ludwig, R.A. 1987. Gene tandem-mediated selection of coliphage $\lambda$-receptive Agrobacterium, Pseudomonas, and Rhizobium strains. Proc. Natl. Acad. Sci. 84: 3334-3338. 
Maniatis, T., E.F. Fritsch, and J. Sambrook. 1982. Molecular cloning: A laboratory manual. Cold Spring Harbor Laboratory Press, Cold Spring Harbor, New York.

Miller, J. (1972) Experiments in Molecular Genetics. Cold Spring Harbor Laboratory Press, Cold Spring Harbor, N.Y.

Mulligan, J.T. and S.R. Long. 1985. Induction of Rhizobium meliloti nodC expression by plant exudate is dependent upon nodD. Proc. Natl. Acad. Sci. USA. 82: 6609-6613.

. 1989. A family of activator genes regulates expression of Rhizobium meliloti nodulation genes. Genetics 122: 7-18.

Murphy, P.J., N. Heycke, S.P. Trenz, P. Ratet, F.J. de Bruijn, and J. Schell. 1988. Synthesis of an opine-like compound a rhizopine, in alfalfa nodules is symbiotically regulated. Proc. Natl. Acad. Sci. 85: 9133-9137.

Nap, J.-P. J. van de Wiel, H..P. Spaink, N. Moerman, M. van den Huebel, M.A. Djordjevic, A.A.M. van Lammeren, A. van Kammen, and T. Bisseling. 1989. The relationship between nodulin gene expression and the Rhizobium nod genes in Vicia sativa root nodule development. Mol. Plant-Microbe Interact. 2: 53-63.

Newcomb, W. 1981. Nodule morphogenesis and differentiation. In Biology of the Rhizobiaceae, (ed. K.L. Giles and A.G. Atherlyl, pp. 247-298. Int. Rev. Cytol. Suppl. 13 Academic Press, New York.

Peters, N.K., J.W. Frost, and S.R. Long. 1986. A plant flavone, luteolin, induces expression of Rhizobium meliloti nodulation genes. Science 233: 977-980.

Ruvkun, G.B. and F.M. Ausubel. 1981. A general method for site-directed mutagenesis in prokaryotes. Nature 289: 8588.

Ruvkun, G.V., V. Sundaresan, and F.M. Ausubel. 1982. Directed transposon Tn5 mutagenesis and complementation analysis of Rhizobium meliloti symbiotic nitrogen fixation genes. Cell 29: 551-559.

Schmidt, J., R. Wingender, M. John, U. Wieneke, and J. Schell. 1988. Rhizobium meliloti nodA and nodB genes are involved in generating compounds that stimulate mitosis of plant cells. Proc. Natl. Acad. Sci. 85: 8578-8582.

Spaink, H.P., C.A. Wijffelman, E. Pees, R.J.H. Okker, and B.J.J. Lugtenberg. 1987. Rhizobium nodulation gene nodD as a determinant of host specificity. Nature 328: 337-340.

Stanfield, S.W., L, Ielpi, D. O'Brochta, D.R. Helinski, and G.S. Ditta. 1988. The ndvA gene product of Rhizobium meliloti is required for $\beta-(1-2)$ glucan production and has homology to the ATP-binding export protein HlyB. I. Bacteriol. 170: $3523-3530$.

Verma, D.P.S., S. Ball, C. Guerin, and L. Wanamaker. 1979. Leghemoglobin biosynthesis in soybean root nodules. Characterization of the nascent and released peptides and the relative rate of synthesis of the major leghemoglobins. Biochemistry 18: 476-483.

Watson, R.J., Y.-K. Chan, R. Wheatcroft, A.-F. Yang, and S. Han. 1988. Rhizobium meliloti genes required for C4-dicarboxylate megaplasmid. J. Bacteriol. 170: 927-934.

Williams, M.N.V., R.I. Hollingsworth, S. Klein, and E.R. Signer. 1990. The symbiotic defect of Rhizobium meliloti exopolysaccharide mutants is suppressed by $l p s Z$, a gene involved in lipopolysaccharide biosynthesis. I. Bacteriol. (in press).

Willmitzer, L. 1988. The use of transgenic plants to study plant gene expression. Trends Biochem. Sci. 4: 13-18.

Yanisch-Perron, C., J. Vieira, and J. Messing. 1985. Improved M13 phage cloning vectors and host strains: Nucleotide sequences of the MI3mpl8 and pUC19 vectors. Gene 33: $103-119$. 


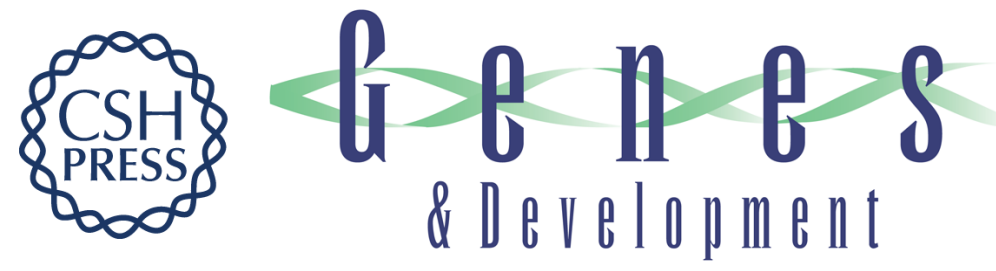

\section{Temporal and spatial regulation of the symbiotic genes of Rhizobium meliloti in planta revealed by transposon Tn5-gusA.}

S B Sharma and E R Signer

Genes Dev. 1990, 4:

Access the most recent version at doi:10.1101/gad.4.3.344

References This article cites 56 articles, 24 of which can be accessed free at:

http://genesdev.cshlp.org/content/4/3/344.full.html\#ref-list-1

License

Email Alerting

Service

Receive free email alerts when new articles cite this article - sign up in the box at the top right corner of the article or click here.

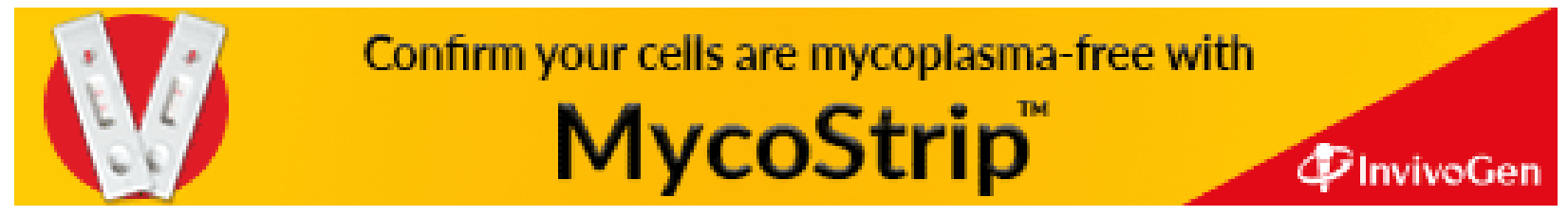

